\title{
Multiple Congenital Granular Cell Tumor in a Neonate - A Rare Case
}

\author{
Aditya Pratap Singh ${ }^{1 *}$, Arun Kumar Gupta ${ }^{1}$, Maryem Ansari $^{2},{\text { Ramesh } \text { Tanger }^{1} \text {, Dinesh Kumar Barolia }}^{1}$ \\ 1 Department of Pediatric Surgery, SMS Medical College Jaipur, Rajasthan, India \\ 2 Department of Pathology, SMS Medical College Jaipur, Rajasthan, India
}

\begin{abstract}
Congenital granular cell tumor (CGCT) is an uncommon congenital benign epulis in neonates. A preliminary diagnosis is usually put forth clinically but may be confused with other anomalies. Herein, we report an unusual case of intra-oral congenital granular cell tumor in a 4-day-old female newborn. The tumor was excised completely. At 3-month follow-up, the baby is doing fine without any recurrence.
\end{abstract}

\section{Keywords: Congenital; Epulis; Granular cell tumor; Neonate}

Correspondence*: Aditya Pratap Singh, Department of Pediatric Surgery, SMS Medical College Jaipur, Rajasthan, India

E-mail: dr.adisms@gmail.com

Submitted: 16-03-2018

Conflict of Interest: None declared (c) 2018, Singh et al

Accepted: 04-05-2018

Source of Support: Nil

This is an open-access article distributed under the terms of the Creative Commons Attribution License, which permits unrestricted use, distribution, and reproduction in any medium provided the original work is properly cited.

\section{INTRODUCTION}

Congenital granular cell tumor (CGCT) is an uncommon congenital benign epulis; other terminologies for CGCT described in the literature are congenital epulis, Granular cell rhabdomyoma, Abrikosov tumor, congenital myoblastoma, or Neumann's tumor.[1] CGCT is nowadays frequently employed terminology in the literature.[2] We are presenting here a case of multiple congenital granular cell tumor of the maxilla in a neonate.

\section{CASE REPORT}

A 4-day-old female neonate presented with an intra-oral growth and difficulty in breastfeeding (Figure 1). There was no respiratory distress. Baby was full term with normal vaginal delivery. The weight of the baby was $2.45 \mathrm{~kg}$. The mother was a primigravida and belonged to a rural area. Antenatal scan was not done. There was no history of any medication during pregnancy nor any congenital anomalies. On local examination, there were multiple pedunculated growths arising from the upper alveolar ridge measuring around $3 \times 2 \times 2$ to $2 \times$ $1 \times 1 \mathrm{~cm}$. The surface of growths was dark reddish. The mass was obstructing the oral cavity. The baby was planned for the emergency surgical excision under general anesthesia. The growths were excised with diathermy. The postoperative recovery was uneventful. Histopathological examination showed a cellular tumor with large polygonal cells having eosinophilic granular cytoplasm and small nuclei. The surface epithelium was stretched over the tumor and was atrophic. The diagnosis was confirmed as congenital granular cell tumor. No bony tissue was seen. There was no recurrence at 3-month follow up.

\section{DISCUSSION}

The CGCT is usually sporadic and has an incidence of $0.0006 \%$ in world population.[3] The most common site of the origin is anterior alveolar ridge; other sites are 
tongue, palate, skin, subcutaneous tissue, skeletal muscles, and the vocal chords. About $90 \%$ cases are seen in female babies with a female: male ratio of $8: 1$. It has no tendency of local recurrence or malignant transformation.[4] Grossly the tumor may present as a firm pedunculated mass arising from alveolar mucosa by means of a stalk.[4] Multiple tumors are seen in $10 \%$ of cases and also seen in the index case.[5]

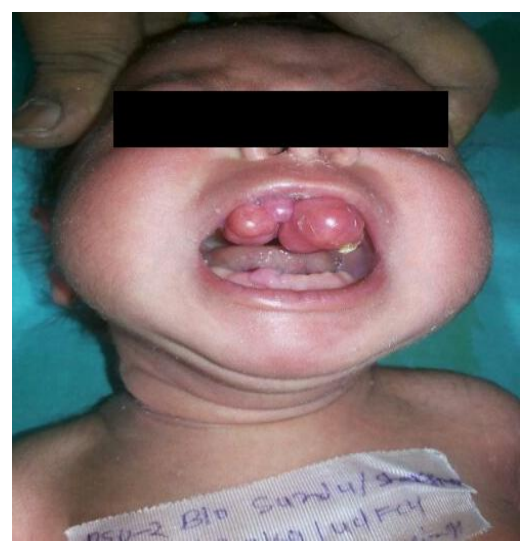

Figure 1: Preoperative photograph.

The tumor is limited to the soft tissue and does not involve deeper tissues such as bone and teeth.[6] It is important to mention that CGCT does not involve or damage the dentition. Reported dentition damage seems to be an iatrogenic damage related to the surgical treatment.[7,8]

Prenatal ultrasound scan or Magnetic resonance Imaging (MRI) may help in such cases. Prenatal diagnosis of CGCT is helpful in the counseling of the parents related to nature and treatment. It may also help in assessing the potential risk of airway obstruction and also the choice of delivery method. Prenatal diagnosis of the CGCT was reported mainly in the third trimester of the pregnancy by ultrasound (USG).[9] In our case, mother had no antenatal checkup.

CGCT may be associated with other congenital anomalies like bilateral transverse facial cleft, polydactyl, congenital goiter and also with neurofibromatosis.[10] While in our case there were no associated anomalies. Although the etiology of congenital epulis is unclear, it is thought to be hormone related, non-neoplastic, degenerative, or reactive lesion.[11]

The accurate diagnosis can be established histopathologically in most of the cases. There are controversies about the origin of CGCT. Some researchers suggest mesenchymal origin while other argue on neuroectodermal origin.[12] Because of the location, potential size of the tumor, and risk of interference with breathing and feeding, complete surgical excision is the treatment of choice.[6-8] Recurrence rarely occurs, and the prognosis is reported to be excellent.[13] Spontaneous regression has been reported in isolated few cases and may occur even in case of incomplete resection.[14] Immunohistochemically, CGCT shows a negative staining for S-100, CD31, CD68, chromogranin, desmin, keratins, and smooth muscle actin. Moreover, a positive staining result is seen for vimentin and neuron-specific enolase.[6] To achieve an accurate diagnosis, it is essential that all data, both histopathologic and clinical, are thoroughly analyzed.[8]

\section{Consent Statement}

Authors declared that they have taken informed written consent, for publication of this report along with clinical photographs/material, from the legal guardian of the patient with an understanding that every effort will be made to conceal the identity of the patient however it cannot be guaranteed.

\section{Author's Contributions}

All authors contributed equally in concept, design, literature review, drafting the manuscript, and approval of the final manuscript.

\section{REFERENCES}

1. Inan $\mathrm{M}$, Yalçin $\mathrm{O}, \mathrm{Pul} \mathrm{M}$. Congenital fibrous epulis in the infant. Yonsei Med J. 2002; 43:675-7.

2. Ruschel HC, Beilke LP, Beilke RP, Kramer PF. Congenital epulis of newborn: report of a spontaneous regression case. J Clin Pediatr Dent. Winter. 2008; 33:167-69.

3. Bosanquet D, Roblin G. Congenital epulis: A case report and estimation of incidence. Int J Otolaryn. 2009; 3.

4. Silva GC, Vieira TC, Vieira JC, Martins CR, Silva EC. Congenital granular cell tumour (congenital epulis): a lesion of multidisciplinary interest. Med Oral Patol Cir Bucal. 2007; 12:428-30.

5. Kannan SK, Rajesh R. Congenital epulis-congenital granular cell lesion: a case report. J Indian Soc Pedod Prev Dent. 2006; 24:104-6.

6. Conrad R, Perez MC. Congenital granular cell epulis. Arch Pathol Lab Med. 2014; 138:128-31.

7. Childers EF, Fanburg-Smith JC. Congenital epulis of the newborn: 10 new cases of a rare oral tumor. Ann Diagn Pathol, 2011; 15:157-61.

8. Saki N, Araghi S. Multiple congenital epulis in alveolar ridges of maxilla and mandible in a newborn: a rare case report. Case Rep Otolaryngol. 2014; (2014), p. 606985.

9. Wittebole A, Bayet B, Veyckemans F, Gosseye S, Vanwijck R. Congenital epulis of the newborn. Acta Chir Belg. 2003; 103:235-7. 
10. Su JM , Wang JM , Gu WZ . Congenital granular cell tumour in a newborn: A case report and literature review in China. HK J Paediatr. (New Series) 2010; 15:165-9.

11. Roy S, Sinsky A, Williams B, Desilets YG, Patenaude. Cogenital epulis: prenatal imaging with MRI and ultrasound. Pediatr Radiol. 2003; 33:800-3.

12. Liang $Y$, Yang $Y S$ and Zhang $Y$. Multiple congenital granular cell epulis in a female newborn: a case report. J Med Case Rep. 2014; 8:413.
13. Bang KO, Bodhade AS, Dive AM. Congenital granular cell epulis of a newborn. Dent Res J. (Isfahan), 2012; 9:136-8.

14. Sakai VT, Oliveira TM, Silva TC, Moretti AB, Santos CF, Machado MA. Complete spontaneous regression of congenital epulis in a baby by 8 months of age. Int $\mathrm{J}$ Paediatr Dent. 2007; 17:309-12. 